\title{
Cartas de alforria: "para não ter o desgosto de ficar em cativeiro"1
}

Maria de Fátima Novaes Pires

USP

\section{RESUMO}

Este artigo trata de alforrias no alto sertão da Bahia, tendo por referência cartas de liberdade, inventários e processos criminais das Comarcas de Rio de Contas e Caetité, antigas vilas e cidades da região. Estabelece quadros comparativos com algumas regiões do Brasil e apresenta os tipos de cartas encaminhadas para a Justiça, durante o século XIX. Palavras-chave: Escravos; Alforria; Liberdade.

\begin{abstract}
This article treats of enfranchisements in the hinterland of Bahia and has for reference 'letters of freedom', inventories and criminal processes of the Districts of Rio de Contas and Caetité, old towns and cities of the area. It compares the region with some areas of Brazil and presents the types of those 'letters' directed to the Justice, during the $19^{\text {th }}$ century. Keywords: Slaves; Enfranchisement; Freedom.
\end{abstract}

Em 1874, o Relatório do Ministério da Agricultura indicava as cifras de 165.403 escravos na Bahia (maior concentração em Salvador e Recôncavo baiano) e 301.352 escravos no Rio de Janeiro. ${ }^{2}$ Nessa mesma época, o alto sertão da $\mathrm{Bahia}^{3}$ revelava uma população escrava estimada em números bem mais modestos, comparados às regiões da economia agro-exportadora. $\mathrm{O}$ Censo de 1862 apresentou no mapa estatístico da população de Caetité "a existência de 4.181 homens e 4.091 mulheres ... 900 escravos (homens) e 675 (mulheres) que correspondiam a 18,83\% dos habitantes recenseados". O Censo Demográfico de 1872 registrou, na freguesia de Caetité, 17.836 habitantes, com 1.058 escravos, correspondendo a 5,9 por cento da sua população. ${ }^{4}$

Os inventários indicaram uma média de cinco a dez escravos por plantel. Esse contingente de trabalhadores manteve-se em padrões regulares no alto sertão, mesmo nas décadas finais da escravidão. Bart Barickman (2003), ${ }^{5}$ ao tratar do sul do Recôncavo baiano, identificou situação próxima ao sertão: 
Vários censos e levantamentos sugerem que, no final do século XVIII e na primeira metade do século XIX, o típico lavrador escravista de mandioca do sul do Recôncavo e de outras partes do litoral baiano possuía de dois a oito cativos ... Era gente assim ... que com os demais roceiros das vilas do sul, produzia os grandes excedentes de farinha de mandioca que abasteciam o mercado regional. (p.248, grifos nossos)

Semelhante às pesquisas de Mônica Dantas (2002, p.174), ${ }^{6}$ para a região de Itapicuru e Soure (norte da Bahia), que indicam "pouco mais de uma dezena" de escravos constituindo os plantéis de senhores daquela região.

As aproximações entre essas regiões do interior da Bahia assinalam que a província não se manteve unicamente às custas de sua economia agroexportadora. Livros de razão de ricos fazendeiros do sertão atestam sólidas relações comerciais com a capital da província, e negam um suposto isolamento dessas economias do interior; situação sinalizada presentemente com o crescimento de estudos regionais. Noutra ponta, nos remetem às dinâmicas relações promovidas pelas tropas e boiadas conduzidas por escravos, forros e trabalhadores livres, ao longo do século XIX.

O exame de alforrias de diversas províncias escravocratas do Brasil permite identificar similaridades em suas condições e concessões, ${ }^{7}$ ao tempo em que a comparação entre as gradações localizadas no alto sertão com pesquisas relativas à "cidade da Bahia" (e ao seu entorno) nos faculta divisar essa região no universo mais amplo da escravidão naquela província.

Os livros de notas do tabelionato de Rio de Contas registraram alforrias de 305 escravos, entre 1870 e 1879, e de 102 escravos, entre 1880 e 1888, totalizando 407 alforrias. ${ }^{8}$ Comparados esses dados com as escrituras públicas de compra e venda de escravos, temos a seguinte situação: entre 1870 e 1879, 305 escravos libertados e o montante de 224 vendidos. Já os inventários indicam, na década de 1870, um total de 933 escravos, ${ }^{9}$ e desse montante as cartas de alforria representam cerca 32,7 por cento. No período seguinte (1880-1888), registrou-se o montante de 102 escravos 'beneficiados' com alforrias e quarenta escravos transferidos mediante vendas. Os inventários, na década de 1880 , registraram um total de 471 escravos, e desse montante as cartas de alforria representam cerca 21,7 por cento. Desses números se depreende um percentual elevado de alforrias na região, que superou, em ambos os períodos, as vendas de escravos em Rio de Contas, confirmando as constantes negociações de escravos com os seus senhores. Uma luta cotidiana, acossada pela presença de traficantes de escravos na região.

Nota-se um número mais elevado de alforrias na década de 1870 — au- 
ge do tráfico interprovincial — comparativamente à década subseqüente. Isso se explica, dentre outros fatores, pelo decréscimo da população escrava naquele momento, mas não se pode perder de vista a correlata intensificação das lutas pela alforria diante da transferência compulsória provocada pelo tráfico interprovincial. O historiador Ricardo Tadeu C. Silva (2000), ${ }^{10} \mathrm{em}$ seus estudos sobre regiões do interior da Bahia, identificou um crescimento progressivo das ações de liberdade ao longo do século XIX. Na sua compreensão, elementos como a Lei do Ventre Livre (de 1871, que oficializava a prática do pecúlio), a extinção do tráfico atlântico, a mudança do eixo econômico do Nordeste para o Sudeste e o advento do movimento abolicionista na Bahia seriam os desdobramentos decisivos a acentuar tal tendência. Mas, certamente, o tráfico interprovincial foi um componente decisivo àquela conjuntura. ${ }^{11}$

Outra informação importante que se depreende da pesquisa está no tipo de cartas 'concedidas'. Dos 407 escravos alforriados, 114 (28\%) receberam cartas incondicionais, 159 (39\%) cartas condicionadas à prestação de serviços e $134(33 \%)$ adquiriram as suas cartas com pecúlio (ver Tabela 1).

Erivaldo Neves (2000) identificou, para a região de Caetité, 174 cartas de alforria entre os anos de 1870 e 1879, números inferiores àqueles que se localizam para Rio de Contas: 226 cartas (com 305 escravos alforriados). As vendas de escravos, mais concentradas naquela região, talvez expliquem essa questão.

O declínio da escravidão sertaneja antecede a intensificação do intercâmbio escravista com o Oeste Paulista ... na década de 1850, logo após o tráfico externo, o número de cartas de liberdade de Caetité declinou 12,4\% comparativamente aos 10 anos anteriores, aumentando $13,3 \%$ no período seguinte e novamente diminuindo $3,3 \%$ no decênio de 1870 , quando se intensificou o tráfico interno. Os valores quantitativos são pouco expressivos, mas revelam dinâmica semelhante que coincide com o período do tráfico. (Neves, 2000, p.105)

Em seu estudo sobre escravos no Rio de Janeiro, entre 1807 e 1831, Mary Karasch (2000, p.451) localizou cerca de 1.319 alforrias entre homens, mulheres e crianças, no meio urbano e rural fluminense. Kátia Mattoso (1990, p.193 $)^{12}$ identificou, entre 1684 e 1888, 16.403 cartas de alforria em Salvador, e citou, numa passagem do seu livro, um estudo de Kiernan sobre alforrias em Parati que lhe possibilitou comparações numéricas:

somente três estudos sobre as cartas de liberdade em Salvador, entre 1684 e 1889 [sic], e um trabalho sobre as concedidas entre 1789 e 1822, em Parati (província do Rio de Janeiro), são esclarecedores de certos aspectos dos contratos de liber- 
tação ... em Salvador, as cartas de alforria concedidas a título oneroso não representam, em momento algum, mais de $48 \%$ do total, enquanto em Parati alcançam apenas 31\%... (Mattoso, 1990, p.184, grifos nossos)

Para essa autora, "um começo de resposta" para a diferença da autocompra entre Salvador e Parati estaria no fato de que "cartas expedidas 'sob condições' ... são mais numerosas em Parati (43\%) do que em Salvador (18\% a 23\%)". Mas não ficam claras as motivações das diferenças.

Eduardo Silva (1997, p.67) ${ }^{13}$ comentou sobre a elevação dos números das alforrias em Salvador:

Kátia Mattoso constatou um crescimento significativo no volume de alforrias concedidas na Bahia entre 1779 e 1850. Da mesma forma, Mattoso, Klein e Engerman, trabalhando com uma amostragem mais ampla, cobrindo de 1819 a 1888 , constataram uma taxa de alforria especialmente alta entre 1840 e 1880 , em torno de $5 \%$ ou $6 \%$ da população escrava de Salvador.

Todavia, o mesmo autor considera que o crescimento de alforrias assinalado em Salvador desde 1819

começou a cair rapidamente no período de 1870 até a abolição final, em 1888.

$\mathrm{O}$ aprofundamento da crise econômica e o empobrecimento geral da sociedade já não parecem facilitar, a partir de então, a compra da liberdade, da mesma forma que passam a dificultar terrivelmente a sobrevivência dos já livres ou libertos. (op. cit., p.68)

No alto sertão, a queda das alforrias na década de 1880, comparativamente à década de 1870, se explica, fundamentalmente, pelas vendas de escravos através do tráfico interprovincial e pela redução do número de escravos na região.

Chalhoub (1990) evidencia articulações entre alforrias e tráfico interprovincial:

segundo Robert Slenes os negros da cidade do Rio nas últimas décadas da escravidão sempre tiveram uma chance mais do que razoável de conseguir a liberdade: nada menos do que $36,1 \%$ da população escrava da matrícula de $1872-73$ recebeu a liberdade até a matrícula de 1886-87. Esses 36,1\% são impressionantes se considerarmos que a porcentagem de negros alforriados no mesmo período na província de São Paulo foi de 11\%, na província do Rio de 7,8\%, na provín- 
cia de Minas 5,6\% ... escravos que se recusavam terminantemente a sair da Corte em direção às fazendas de café do interior. (p.158, grifos nossos)

Mônica Dantas (2002) assinalou uma tendência às alforrias na Bahia, fruto das vicissitudes da indústria açucareira e, posteriormente, do surto da mineração, confirmando os trabalhos de Maria Odila L. S. Dias e Caio Prado Jr., muito interessados em discutir a inserção dessas populações em novas dinâmicas da vida social ao "transbordarem dos interstícios dos engenhos para sítios e terras" (Dias, no prelo, p.20, apud Dantas, 2002, p.39).

Desde fins do século XVII, a Bahia vinha experimentando o crescimento de uma população de homens livres: pardos, mulatos e negros forros ... Esses novos grupos buscavam sua subsistência em todo tipo de ocupação ou região, subsidiárias às atividades de exportação. Sua presença passou a ser fortemente sentida não só nos núcleos urbanos como Salvador, mas também em regiões rurais economicamente menos expressivas. (Ibidem, grifos nossos)

A documentação pesquisada mostra, em variados momentos, a presença de populações migrantes que passaram a viver nos termos de Rio de Contas e Caetité, geralmente ao lado de escravos, forros e trabalhadores livres. Também evidencia deslocamentos para áreas próximas ou mais longínquas daqueles que ali moravam. E, ainda, que muitos forros continuaram a viver (mesmo que provisoriamente) nas antigas vilas do sertão; alguns chegaram a adquirir escravos.

Esse trânsito (físico, cultural e comercial) permitiu teias de informação e formas de sociabilidades engendradas por aqueles que transitavam por entre os pequenos núcleos urbanos e arrabaldes. De acordo com Paiva (1995), esses constantes deslocamentos afetaram a dinâmica das alforrias e as possibilidades de ascensão econômica e social de forros em Minas Gerais, situação que provavelmente se repetiu em áreas como Rio de Contas e Caetité.

O exame das condições das cartas de alforria, obedecendo às tipologias de condicionais, incondicionais e compradas, nos faculta alguns indícios dessa situação. Entabulemos essa abordagem.

\section{CARTAS CONDICIONADAS}

Mary Karasch (2000, p.439) definiu a carta de alforria como "prova da liberdade de um escravo, introduzindo-o na vida precária de uma pessoa liberta numa sociedade escravista”. Para Kátia Mattoso (1990, p.178), “A liberdade pela alforria é um dispositivo legal ... Em geral, esta é concedida em do- 
cumento escrito ... O proprietário renuncia assim voluntariamente a seu manus sobre o cativo...". Nestes termos, competia ao sistema judiciário não somente reconhecer e legitimar, mas assegurar o cumprimento dos acordos assinalados nas cartas.

No alto sertão, onde os plantéis variavam na média de cinco a dez escravos, a posse escrava definia níveis de riqueza e a sua aquisição não se fazia com folga, diante das condições econômicas mais modestas da ampla maioria dos senhores daquela região. Nessas condições, as alforrias representavam, para a década de 1870, 32,7 por cento dos escravos inventariados e, na década de 1880, 21,7 por cento. Muito embora essa proporção se revele relativamente elevada - 1/3 do montante inventariado - é preciso considerar as modalidades dessas cartas.

A Tabela 1 mostra que 33 por cento dos escravos compraram as suas alforrias; 28 por cento foram concedidas incondicionalmente e 39 por cento, a percentagem mais elevada, foi condicionada a serviços.

\section{Tabela 1}

Condição das alforrias, Rio de Contas - 1870-1888

\begin{tabular}{l|c|c|c|c}
\hline Período & Incondicionais & $\begin{array}{c}\text { Condicionadas } \\
\text { a serviço }\end{array}$ & $\begin{array}{c}\text { Número } \\
\text { de compras }\end{array}$ & $\begin{array}{c}\text { Valores médios } \\
\text { (Rs.) }\end{array}$ \\
\hline $1870-1871$ & 14 & 29 & 32 & 580.000 \\
$1872-1875$ & 26 & 77 & 39 & 450.000 \\
$1876-1879$ & 22 & 25 & 28 & 390.000 \\
$1880-1885$ & 17 & 11 & 8 & 354.000 \\
$1886-1888$ & 114 & 159 & 134 & 255.000 \\
\hline Qtde. Escravos & 22 & 17 & - \\
\hline
\end{tabular}

Fonte: AMRC. Seção Judiciário. Livros de Notas do Tabelionato. Série cartas de liberdade. Nota: Valores médios em Rs. (réis).

A concessão 'gratuita' de uma alforria 'sob condição' constituía-se muito mais numa estratégia de controle do que numa demonstração de generosidade por parte dos senhores. Essa situação foi assinalada, em outros trabalhos:

Será realmente 'gratuita', como gostam de escrever certos senhores, essa liberdade concedida sob a condição de o forro permanecer escravo enquanto vivos 
forem o senhor, ou seu filho, sua irmã ou qualquer dos outros membros da família? Na verdade, ela é paga muito caro, é sempre revogável e torna o escravo libertável ainda mais dependente, pois ele sabe que a menor desavença, um instante de mau humor, pode pôr abaixo o edifício duramente construído de sua futura libertação. (Mattoso, 1990, p.184)

Eduardo Paiva (1995, p.50) observa a mesma situação em Minas Gerais: "Essa 'gratuidade' acabava sendo compensada com árduo trabalho, humilhações e discriminação”. Mas também não resta dúvida de que, mesmo sob condições, a alforria foi "o feliz resultado de uma negociação cotidiana com o senhor” (Bellini, 1988 apud Reis \& Silva, 1989, p.17). ${ }^{14}$

As cartas 'concedidas' pelos senhores trazem, de um modo geral, menções como estas: "pelo muito amor que lhe tenho", "pelos bons serviços prestados", "pelo amor e confiança", "por gratidão e amor", "pelo amor e pela graciação". Em comum, beneficiavam senhores e senhoras, que não as outorgavam efetivamente enquanto "vida tivessem", como se vê nesta referência: "me servindo e obedecendo durante minha vida". ${ }^{15}$ Outras submetiam a concessão ao tempo de vida de filhos e netos. Para Erivaldo Neves (2000, p.105), esse seria um sintoma de regiões mais modestas: "Condicionar a libertação de uma jovem à permanência no cativeiro enquanto viver — sugere escravidão doméstica e convívio senhor-escravo...”.

Muitos dos jovens escravos ficavam por anos a fio no convívio de uma mesma família, talvez isso explique o fato de muitas cartas, "condicionadas à prestação de serviços", serem também concedidas a escravos bastante idosos: "Liberto a minha escrava Antonia Africana, de idade de 60 annos pouco mais ou menos, com a condição de me acompanhar até o dia do meu fallecimento pela mesma maneira que tem me servido". ${ }^{16}$ Ou a carta de Simplicia, "parda de 70 anos", de Antonio Gomes Correia: "pelos bons serviços que me tem prestado e com a condição de me servir e acompanhar, como sempre tem feito, depois de meo fallecimento". ${ }^{17} \mathrm{Ou}$ ainda a carta de "Francisco de 80 annos de idade, cuja liberdade lhe concedemos gratuitamente, com declaração porém de assistir em suas companhias, isto é, de mim José Antônio Ribeiro enquanto for vivo, não sendo pelos libertandos perturbado". ${ }^{18}$ Alguns senhores preferiram manter em seu poder escravos anciãos e/ou senis a fim de poupá-los da mendicância. Noutros momentos, esse domínio ou apego se revestia da mais pura perversidade por parte dos senhores.

As cartas também evidenciam outras formas de estabelecer o controle sobre escravas e escravos. Localizam-se, com muita regularidade, condições 
que agravavam ainda mais a crueldade de sua 'concessão'. É preciso lembrar que: "Forros, ainda assim se manteriam ligados a seus senhores, que poderiam revogar a alforria concedida, alegando ingratidão." (Mattoso, 2000, p.156). De acordo com essa autora (op. cit., p.180), a suspensão da prerrogativa ocorreu "somente após 1865 (quando) os tribunais declararam inadmissível tal procedimento".

Na carta de Catharina, escrava de Manoela Sofia de Castro, constava que deveria: "criar os filhos que tiver minha filha ... Se porem faltar a referida escrava á condição estipulada, recomendo a todos os meos herdeiros que considerem sem nenhum effeito esta alforria". ${ }^{19}$ Mais duas referências: a carta da escrava Rosa, de 37 anos: "de servir minha mulher 7 annos com respeito e obediência sob pena de ficar sem efeito se não for cumprida”. ${ }^{20}$ A escrava Maria Isabel, de D. Luiza Maria da Trindade, deveria "me servir em quanto viva eu for, e se por ventura casar durante minha existência, fica sem efeito a carta". ${ }^{21}$ Não resta dúvida de que, também no sertão, "a luta dos cativos pela alforria aparece geralmente num tecido mais amplo de relações e conflitos" (Chalhoub, 1990, p.111). O referido autor demonstrou, através do cruzamento de ações de liberdade e autos criminais, a validade desse aspecto no Rio de Janeiro.

Senhoras libertavam filhos de suas escravas alegando geralmente "pelo muito amor", como foi o caso de "Manoel crioulo", filho de "Maria cabra", alforriado: "com a obrigação de servir-me a mim enquanto for viva cuja graça lhe faço de muito minha livre vontade ... pelo muito amor, que lhe tenho". ${ }^{22}$ Como se vê, a ampla maioria dessas cartas condicionava-se a "servir-me em quanto for viva" ${ }^{23}$ e revela as intenções de permanência de dominação por parte dos senhores do sertão. O escravo Sebastião foi liberto, "para gozar sua liberdade em minha companhia para não ter o desgosto de ficar em cativeiro"..24

Como se demonstra na Tabela 2, as crianças alforriadas representaram aproximadamente 22,5 por cento das cartas nas décadas de 1870 e 1880 . Também no sertão, a 'libertação’ das crianças se explica, geralmente, pelo fato de 'serem crias': "o qual nascido em poder e criado em meus braços e pelo amor que lhe tenho". ${ }^{25}$ Segundo Mary Karasch (2000, p.457), essas "expressões de amor em relação às crias documentam os laços familiares e de amizade que levavam seus donos a dar-lhes a liberdade”. Cabe observar, no entanto, que muitas dessas 'expressões de amor' não dispensavam a manutenção da condição de escravo para as crianças, que deveriam aguardar até o fim da vida de seus senhores. 
Tabela 2

Escravos alforriados (gênero e idade), Rio de Contas - 1870-1888

\begin{tabular}{c|c|c|c|c|c|c}
\hline \multicolumn{5}{c|}{ Homens } & \multicolumn{3}{c}{ Mulheres } \\
\hline Década & 1870 & 1880 & Total & 1870 & 1880 & Total \\
\hline Adulto & 72 & 35 & 107 & 92 & 57 & 149 \\
$(\%)$ & 51,4 & 83,3 & 58,8 & 60,9 & 77 & 66,2 \\
Criança & 41 & - & 41 & 41 & 9 & 50 \\
$(\%)$ & 29,3 & - & 22,5 & 27,2 & 12,2 & 22,2 \\
Idoso & 27 & 7 & 34 & 18 & 8 & 26 \\
$(\%)$ & 19,3 & 16,7 & 18,7 & 11,9 & 10,8 & 11,6 \\
\hline Total & 140 & 42 & 182 & 151 & 74 & 225 \\
$(\%)$ & 34,4 & 10,3 & 44,7 & 37,1 & 18,2 & 55,3 \\
\hline
\end{tabular}

Fonte: AMRC. Seção Judiciário. Livro de Notas do Tabelionato. Série cartas de liberdade.

Outras cartas 'concedidas' às crianças enfatizavam a necessidade de libertá-las somente depois de "receber a educação e adquirir meios de sua subsistência”. ${ }^{26}$ Alguns documentos da região explicitaram intenções muito próximas dos debates que envolveram a Lei do Ventre Livre.

termo de tutela dos menores libertos Joaquim e Laurinda ... filhos naturaes da liberta Victoria; tratando e zelando de suas pessoas como desvalidos, dando-les a educação moral instructiva e religiosa, compatível com suas forças e posição dos ditos menores, cumprindo em tudo todos os deveres humanitários e protecção que merecem, e ultima vontade manifestada pelo senhor dos mesmos menores e seo tio Marcolino. ${ }^{27}$

Deve-se considerar que as vendas de escravos, intensificadas na década de 1870, levaram muitos senhores a assumir a criação de crianças deixadas na região, sob pena de perdê-las por abandono. Conrad (1975, p.141, grifos nossos) observa este aspecto: 
A mais grave crítica apresentada contra a Lei Rio Branco talvez tenha sido no que se refere a seu fracasso em conceder ao ingênuo médio uma vida muito diferente da do escravo médio. Um membro do Conselho de Estado do Imperador afirmou publicamente, em 1884, que os filhos livres de mulheres escravas, que também eram chamados, na gíria do tempo, riobrancos, tinham sido mantidos "em quasi totalidade, na mesma condição servil como os demais escravos, faltando-se-lhes com a indispensável e devida instruç̧ão e desamparados da proteção tutelar da autoridade pública".

As cartas 'concedidas' às crianças, geralmente condicionadas à prestação de serviços, sugerem mais uma vez os reflexos do debate político da referida lei nos papéis judiciários. Gebara $(1986, \text { p.51 })^{28}$ explica que

a lei [de 1871] tinha a seguinte estrutura: primeiramente foi decretado que os filhos de escravos nascidos após 28 de setembro de 1871 seriam livres. Estas crianças permaneceriam sob os cuidados dos donos, que por sua vez seriam obrigados a cuidar delas e educá-las até o oitavo ano de vida. Depois, o proprietário poderia opcionalmente ou receber uma indenização de $600 \$ 000$ por criança (em títulos do governo com rendimento de 6\%), ou utilizar os serviços do menor até que este completasse 21 anos. Todas as crianças que fossem abandonadas por senhores deveriam ser educadas por associações criadas com esse propósito.

Algumas cartas ilustram essa questão com riqueza de detalhes. Em um trecho, extraído de uma carta de liberdade assinada por Dona Olympia Carvalho, uma senhora riocontense, além deste aspecto, novamente se percebe uma demonstração da importância da posse de crianças escravas naquela região:

Digo eu abaixo assignada, que tendo meu marido Raimundo Soares de Souza sem motivos justificados repudiado-me para casa de meo Pai, onde me acho e tendo o mesmo para prejudicar-me já vendido as escravas Maria e Emerencia de meo dote e mais os escravos Torquato e Zeferina de herança do Pai, e pelo amor que tenho aos escravinhos Benvenuto, crioulo, de nove annos de idade e Benedicta, cabra, de quatro, os liberto condicionalmente, o primeiro para servir a meo Pai e na sua falta a mim, e o segundo só a mim, todos até completarem a idade de 25 annos, depois do que gosarão de plena liberdade como se de ventre livre nascessem ... Olympia Josefina Bastos de Carvalho. ${ }^{29}$

Diante do escasso plantel de muitos sitiantes e lavradores, o trabalho dos 
pequenos escravos se mostrava valioso. Em tenra idade, trabalhavam na lavoura e com o gado, carregando água das fontes, ou como aprendizes nas oficinas de ferreiros, seleiros, latoeiros... As meninas, desde cedo, aprendiam com as mães as habilidades da cozinha e da costura, a lavar e a engomar, todas as artes do serviço doméstico, mas, certamente, também buscaram escapar dessas rotinas fatigantes. Nos extensos quintais, cercados de árvores, acompanhadas de bonecas de pano e ossinhos de boi, viveram o roubado tempo da infância.

O raro registro de reconhecimento da paternidade por parte dos senhores é um outro aspecto das cartas concedidas a crianças. Mas houve exceção: duas cartas de alforria a dois jovens escravos, que, apesar de gratuitas, opunham restrições. ${ }^{30}$ A primeira delas do escravo "Pardo Dionísio, molato [sic] de 12 annos", de Ricardo Corrêa e Silva, "o qual forro pela muita amisade que lhe tenho, e por conhecer que é meu filho, com a condição convem de me acompanhar durante a minha vida e para não prejudicar á meus herdeiros tomo seu valor na minha terça". ${ }^{11}$ E uma outra, da escrava Cantidiana, "mulatinha de seis anos", alforriada pelo mesmo senhor Ricardo Corrêa Silva: "a qual forro pela muita amizade que lhe tenho, e por reconhecer que é minha filha, com a condição porem de me acompanhar durante a minha vida e para não prejudicar á meus herdeiros tomo seu valor em minha terça...." ${ }^{32}$ Noutra carta, de "Antonio pardo, filho da escrava Constança, de d. Francisca Maria da Silva", não fica claro o nível de parentesco, diz-se apenas: "por conhecer ser o mesmo meu parente em próximo gráo”. E, novamente, caberia a Antonio "acompanhar-me a mim e ao meo marido, em quanto vivermos...." ${ }^{33}$ As restrições dessas cartas expõem as ambigüidades da alforria condicional na sociedade escravista. Servem mais à dissimulação dos interesses senhoriais e à manutenção de suas prerrogativas de mando e posse do que efetivamente à vontade de cessão da 'liberdade'. Como nos lembra Chalhoub (1990, p.100):

cada cativo sabia perfeitamente que, excluídas as fugas e outras formas radicais de resistência, sua esperança de liberdade estava contida no tipo de relacionamento que mantivesse com seu senhor particular ... a concentração do poder de alforriar exclusivamente nas mãos dos senhores fazia parte de uma ampla estratégia de produção de dependentes, de transformação de ex-escravos em negros libertos ainda fiéis e submissos a seus antigos proprietários.

A partir da década de 1870, as 'cartas condicionais' apresentaram um outro aspecto: passaram a estabelecer prazos para a 'concessão' da alforria, pro- 
vavelmente como resultado de uma conjuntura menos favorável à escravidão. Utilizar a carta como expediente de controle, sem delimitar um período para a sua efetivação, talvez não se revelasse uma estratégia tão eficiente naquele momento. Diante disso, a saída de muitos senhores foi recorrer aos 'prazos', tal como aparece na carta concedida pelo senhor Salvador da Luz Soares à sua escrava "Sophia, parda, de 50 anos, casada ... com meo escravo de nome Jeremias ... com a condição de ainda me servir trez annos". ${ }^{34}$

Outras cartas, expedidas nos anos que sacudiram a escravidão, revelam as dificuldades dos sujeitos sociais em antecipar as conjunturas históricas. Em 1878, a cozinheira Margarida "crioula" recebeu a sua carta: "lhe concedamos d'esta data a 12 anos quer estejamos vivos quer não...”. ${ }^{35}$ Dentre vários registros dessa natureza, há o caso de Romualda, “crioula", de 50 anos: "para servirnos como própria escrava que é por espaço de 20 anos contando desta data em diante, se nós por ventura morrermos ficará servindo a meu filho Bacharel João Carlos Borges, na falta dele algum filho dele". ${ }^{36}$ Com a mesma disposição, o Sr. Octaviano Xavier Cotrim alforriou o seu escravo Gastão, "único que deste nome temos", com prazo totalmente calculado "de nos servir por mais 5 anos, a contar de Dezembro de 1886 a dezembro de 1891". ${ }^{37}$

A extensão desses prazos revela uma crença na vitalidade da escravidão, imaginada por muitos senhores. Sobre este aspecto B. J. Barickman (19981999, p.229) ${ }^{38}$ afirma:

Na verdade, ainda em 1881, os proprietários de escravos, não só na Bahia, tinham motivos racionais para esperar que o regime servil ainda se mantivesse no Brasil até o fim do século e, talvez, até 1910. Ou seja, erraram em seu cálculo da longevidade política da escravidão. Mas seu erro não demonstra sua irracionalidade; atesta, antes, sua incapacidade de prever o futuro com certeza absoluta.

A partir de 1875 também se observa, nos livros de notas do tabelionato de Rio de Contas, um registro mais amplo de alforrias coletivas. Como se vê, a título de exemplo, nesta carta expedida pelo senhor Luiz Pereira de Mello:

Izabel parda de 2 anos, filha legítima de nosso escravo Gregório. Benedicta parda casada, gozará da inteira liberdade desta data em diante [maio de 1875]. Maria Rosa casada gozará de sua liberdade dous anos a partir desta data de 1875, quer estejamos vivos ou não. Gregório, nosso escravo, casado com Maria Rosa desta data de 1875 a cinco anos quer estejamos vivos ou não. Sertorio que lhe 
concedo a liberdade, que lhe acompanha desde a infância até os fins dos meus anos. $^{39}$

Mesmo coletivas, essas cartas parecem distantes de refletir os sintomas averiguados na região fluminense: "Não apenas através das concessões de alforrias os ex-senhores tentaram responder e se antecipar ao acelerado desmonte da ordem escravista" (Mattos, 1998, p.239). ${ }^{40}$ Mesmo que um ou outro senhor tenha se convertido à causa abolicionista em Rio de Contas e Caetité, não se observa nenhuma manifestação organizada que explique essas alforrias. Para aquelas regiões do sertão, assim como em outras partes do Brasil, é mais certo pensar nos efeitos da conjuntura mais cambaleante da escravidão a partir daquele momento.

Cartas 'condicionadas', tão comuns em seus termos, como nesta de "Antonio cabra", de 20 anos de idade, escravo de D. Maria Clemência de Moraes, "de ficar em minha companhia, obedecendo as minhas ordens até minha morte, depois disto ficará de todo livre, senhor de si, e de sua vontade...", ${ }^{41}$ asseveram, de um modo geral, a análise sugerida por Algranti (apud Wissenbach, 1998, p.69-70): :2 "a concessão ou a promessa de alforria, mais do que sinal de benevolência senhorial, apresentava-se como artifício utilizado para a consecução do domínio escravista”.

\section{CARTAS COM PECÚlio - A AUTOCOMPRA}

Ilm. Ex. Sr. Presidente da Província da Bahia.

Rosendo Vasq. [sic] da Costa, há dez annos ausente da sua província natal Sergipe da qual viera para esta Capital como escravo e trabalhando com excessivas forças, poude ao cabo de oito annos conseguir o seu mais ardente desejo a liberdade, e desejando agora ir para o seio de sua família, da qual se apartara ainda creança, e não tendo meios pecuniários para a sua viagem, pede a benévola proteção de V. Exa. Para esse fim, dando-lhe uma passagem para a Estância no vapor Gonsales Martino, que segue no dia 20 para ali; contando, e agradecendo desde já, com a philantropia de V. Exa.: nestes termos. Março de $1876{ }^{43}$

Esse documento refere-se a um escravo morador da "capital da Província da Bahia". Nele se observam vários elementos, dentre eles: o desejo da liberdade, a vontade de encontro com a família, as vendas de escravos crianças entre províncias do Nordeste, e ainda a difícil constituição do pecúlio por par- 
te de um escravo. Em Rio de Contas e Caetité, verificam-se muitas trajetórias próximas à de Rosendo. As cartas compradas com pecúlio escravo mostram que a participação de escravos na microeconomia regional não foi desprezível. Entre 1870 e 1880, dos 407 escravos alforriados em Rio de Contas, cerca de 33 por cento adquiriram as suas cartas com pecúlio.

A constituição de pecúlio por parte do escravo sugere sua participação nas atividades econômicas informais desenvolvidas em várias partes do Brasil. A historiadora Maria Helena P. T. Machado (1988, p.148) ${ }^{44}$ adverte:

as atividades autônomas referem-se, em primeira análise, à questão das roças e sua profunda conexão com o desenvolvimento do pequeno comércio em torno das fazendas, vilas e cidades. Porém, ainda outras atividades escravas autônomas devem ser consideradas: $\mathrm{o}$ artesanato, a pesca, a coleta, a prestação de serviços remunerados realizados dentro ou fora das fazendas, no tempo livre disponível pelo escravo, as gratificações e prêmios embutidos no próprio regime de trabalho das fazendas, finalmente, e por que não, os furtos e desvios da produção agrícola empreendidos pelos escravos, que constantemente atormentavam a vida dos senhores.

Essa situação se repete em vários estudos e remove a idéia de sua atipicidade. Revela, sobretudo, que os escravos aprenderam formas preciosas de sobrevivência que favoreceram ajustes, mitigaram a dureza de suas vidas e contribuíram na constituição de pecúlio para compra de suas alforrias.

Outras referências ao pecúlio podem-se localizar no trabalho de Eduardo F. Paiva (1995, p.49) sobre alforrias mineiras do século XVIII. Para o historiador, a conjuntura da região favorecia a manumissão:

O extenso território mineiro experimentou rápida e descentralizada urbanização; a economia diversificou-se já nas primeiras décadas do Setecentos, impondo um padrão monetarizado mesmo entre as mais ordinárias relações de troca; enormes levas de aventureiros fixaram-se nas Minas e decretaram a entrada frenética de escravos africanos e crioulos ... proprietários, muitos deles, viviam e trabalhavam lado a lado com seus escravos na mineração, na agropecuária, no comércio e nos serviços oficiais mecânicos...

Sidney Chalhoub (1990, p.159) alerta para o reconhecimento legal da lei de 1871 sobre o pecúlio, e mais: "foi o reconhecimento legal de uma série de direitos que os escravos haviam adquirido pelo costume e a aceitação de alguns objetivos das lutas dos negros". 
Eduardo Silva (1997, p.142) também esclarece que esse 'direito' foi conquistado antes mesmo da aprovação dessa lei, "que não precisou de um diploma legal específico, mas veio de carona, quase imperceptível, no bojo da chamada Lei do Ventre Livre". Afirma que, antes de legalizado o direito de manter pecúlio e o de comprar a própria liberdade ("conquistas antigas" em tempos ainda não precisados pela "ausência de pesquisa específica"), os senhores

dificilmente ousariam enfrentar a indignação de um homem que batalhou tostão por tostão ("em suas horas vagas", segundo os costumes) para comprar a própria liberdade, sobretudo numa cidade como a Corte. Caso o fizesse, enfrentaria não apenas a revolta pessoal do escravo, que poderia fugir, ou, mais freqüentemente ainda, recusar-se a qualquer colaboração eficiente. Enfrentaria a desaprovação social aberta, a terrível língua grande do povo miúdo. Essa opinião pública, irreverente e severa, própria das "camadas baixas do povo", manifestar-se-ia fatalmente "com grande intensidade", expressando sua desaprovação ao senhor "por todos os meios".

De acordo com Paiva (1995, p.50), essa conjuntura contribuía para a "flexibilização das relações escravistas; os acordos cotidianos entre proprietários e propriedades; a atuação mais autônoma dos escravos nas economias locais; a formação de pecúlio e a virtualidade da libertação". Não resta dúvida de que, apesar das distintas conjunturas, essa situação também se repetiu no alto sertão.

Data de longe a prática de constituição de pecúlio no alto sertão. Spix e Martius (1916), ${ }^{45}$ que passaram pelo alto sertão na primeira década do século XIX, compraram milho "das roças de escravos" para alimentar seus animais durante a viagem. Lycurgo Santos Filho (1956, p.121), ${ }^{46}$ em sua pesquisa sobre a Fazenda do Brejo do Campo Seco (localizada na vila de Bom Jesus dos Meiras - atual Brumado, BA), confirma:

Viu-se que escravos do Familiar (século XVIII) possuíram éguas de criação. Pois Pinheiro Pinho também permitiu que negros seus plantassem e criassem, possibilitando-lhes amealhar haveres que serviram para gastos diversos e para a compra da alforria.

No curso do século XIX e início do século XX, Rio de Contas e Caetité mantinham suas economias muito voltadas para o cultivo de gêneros de subsistência (roças de mantimento), criação de gado e tropeirismo. Alguns senhores mais abastados combinavam essas atividades com as culturas de ex- 
portação do algodão, realizando articulações comerciais e financeiras com Salvador, Recôncavo e Minas Gerais. A dinâmica urbana daquelas vilas pode ser considerada insignificante comparada à das Minas setecentistas, "principal centro colonial” (Paiva, 1995, p.49), no entanto, ao tratar das relações entre senhores e escravos, Paiva assinala situações próximas àquelas experimentadas nas pequenas vilas do alto sertão da Bahia. Como explicar essa situação? A proximidade entre senhores e escravos nas lidas cotidianas favoreceria a manumissão? Mary Karasch (2000, p.453) chamou atenção para o fato de que nem sempre a proximidade foi garantia de "amor e afeição", muitas vezes "a proximidade também gerava inimizade”. Mas não se pode desprezar na complexa rede das relações cotidianas entre senhores e escravos aspectos como afetividade, gratidão...

De outro modo, não resta dúvida de que as urgências e dificuldades dessas economias, junto com as pressões de escravos, impulsionaram os senhores a alargarem - mesmo contrariando algumas de suas prerrogativas - $\mathrm{o}$ lastro da autonomia escrava. Era melhor permitir-lhes a busca de sustento próprio do que se onerar ou se ocupar com mais encargos. No caso do alto sertão, a seca agravava ainda mais esse quadro. Grosso modo, sabe-se que, na região das Minas, no Setecentos, a produção para subsistência não deixou de ser um problema relevante. Talvez essas dificuldades 'aproximassem' essas regiões quanto às condições de negociação da alforria.

As formas de reunir pecúlio estiveram diretamente relacionadas aos arranjos cotidianos, constituídos nas redes de vizinhança e parentesco, que ampliaram as margens de negociações com senhores locais. Os escravos do alto sertão realizavam pequenos negócios, prestavam serviços diversos, vendiam mantimentos nas feiras, conseguiam empréstimos, trabalhavam nas tropas ou como artífices nas oficinas manufatureiras das vilas. Também estavam cientes de que "[a] melhor chance de negociar a liberdade com o senhor era juntar as economias e conseguir indenizar seu preço" (Chalhoub, 1990, p.160). $\mathrm{Na}$ carta da escrava "Ignês preta", solteira, de 45 anos, constata-se que "pagou por sua liberdade a quantia de $146 \$ 000$ reis, mais dois anos, para obter taxas em moagem de assucar". ${ }^{47}$ Nessa ação, percebe-se que interessava ao escravo assegurar não somente a sua liberdade, mas meios de subsistência como forro, garantindo de uma só vez mecanismos para desempenho de atividades rentáveis, possivelmente já partilhadas em suas rotinas enquanto cativos.

Diferente de Salvador, um centro urbano dinâmico, onde os escravos que obtinham dinheiro para alforria eram "sobretudo aqueles, homens ou mulheres, que exercem ofícios cujo salário diário é dividido com o senhor ... as 
pequenas atividades comerciais ou artesanais são as que se mostram mais rentáveis para o escravo ansioso de libertação...” (Mattoso, 1990, p.171, 188); no alto sertão, a maior parte deles foi identificada como do "serviço da lavoura".

João Reis e Eduardo Silva (1989, p.17, grifos nossos), ao se referirem às lutas pelas alforrias, identificaram outras formas de adquirir pecúlio na capital baiana:

Além das fugas e insurreições, a liberdade podia ser obtida, ainda, através da criatividade, da inteligência e do azar. Alguns procuram aproveitar conjunturas favoráveis ... Outros ... esfalfavam-se em serviços extras e depositavam suas economias, de tostão em tostão, na caderneta da Caixa Econômica. Outros ... mais confiantes na boa estrela do que em cadernetas, arriscavam as economias em bilhetes de loteria e sonhavam com o prêmio da liberdade. Outros ainda, recorrem a expedientes ilícitos, como o roubo, ou espremem o cérebro em complicados planos.

No alto sertão, cuja economia foi essencialmente agropastoril, a situação se parece mais próxima àquela assinalada nos estudos de Barickman (2003, p.113-5) sobre os distritos do Recôncavo baiano:

podiam alcançar um grau restrito, mas mesmo assim real, de autonomia no cultivo de suas roças e em outras atividades que desenvolviam em seu tempo 'livre' ... a venda de excedentes por esses escravos era uma prática comum e regular ... Muitas vezes, suas roças deviam ser meros retalhos de terras; as horas que a elas podiam dedicar, sem dúvida, eram poucas; e em geral as colheitas deviam ser mesquinhas. Mas no cultivo dessas roças, eles mesmos, não seus donos, tomavam as decisões.

A venda de reses também foi outra forma de adquirir pecúlio. Sabe-se que vaqueiros recebiam pelo sistema de sorte ou giz, ${ }^{48}$ mas não há provas de que escravos partilhassem dessa espécie de bônus. Entretanto, escravos vaqueiros, tornados forros, poderiam utilizá-lo para a compra da alforria de seus familiares, como se observa nas referências ao gado como pagamento em diversas cartas de alforria. Outros mais poderiam empregar algum dinheiro em animais e revendê-los em ocasião considerada mais oportuna.

Vários registros demonstram que a forma de pagamento da alforria era realizada primeiramente em espécie: "pela quantia de $750 \$ 000$ que recebi da dita escrava [Maria, preta, 30 anos, casada com o meu escravo José, cabra] em 
moeda corrente". ${ }^{49}$ Em outros se vê a recorrência à moeda e à criação, como foi o caso de "Antonio preto Africano, escravo de Francisco dos Santos Caldas. Pago a quantia de $200 \$ 000$, sendo $86 \$ 000$ em mor [ sic] e o resto em animais que possuía"..$^{50}$ Os inventários também registravam as dívidas dos escravos com a compra de suas cartas: "uma dívida activa de $450 \$ 000$, produto da liberdade dos escravos Alexandre e David". ${ }_{11}$

Sem dúvida, "as cartas dão um breve retrato dos escravos que ganhavam a liberdade" (Karasch, 2000, p.440), mas também muito revelam daqueles que a 'concederam'. Diante das condições econômicas mais modestas dos senhores do sertão, as formas de pagamento das cartas revelam que parte deles se valia de pertences muito simples de seus escravos:

Florêncio Preto de 25 annos de idade solteiro [lavrador] de José Moreira Barbosa ... Pagou pela sua liberdade não só a quantia de 150\$000 reis em dinheiro e também certas creações e alguns trenzinhos que ele possui, de minha muito livre vontade...52

Ou ainda:

Theresa, crioula, 60 annos mais ou menos, que a houve por dote do finado meo sogro ... a qual forro e assim forra fica de hora em diante sem condição, visto os bons serviços que me tem prestado e deixado produções para mim e meos herdeiros ... João Fernandes de Souza. ${ }^{53}$

Verifica-se na Tabela 3 que, das 407 cartas de alforria registradas em Rio de Contas, 75 por cento foram concedidas pelos senhores, enquanto as mulheres se responsabilizaram por 25 por cento delas. Diferencia-se da pesquisa de Mary C. Karasch (2000, p.447) sobre as alforrias no Rio de Janeiro: “58\% eram [concessões] do sexo masculino, $42 \%$ do sexo feminino”. Para essa autora, esse equilíbrio se justificaria porque:

A mulher ... tendia a libertar suas criadas domésticas fiéis e suas crias, preferindo a alforria condicional a fim de garantir que as cativas continuassem a trabalhar para ela até sua morte. 
Tabela 3

Alforrias concedidas (gênero), Rio de Contas - 1870-1888

\begin{tabular}{c|c|c|c}
\hline Décadas & 1870 & 1880 & Total \\
\hline Senhores & 221 & 78 & 299 \\
$(\%)$ & 72,5 & 76,5 & 73,5 \\
Senhoras & 84 & 24 & 108 \\
$(\%)$ & 27,5 & 23,5 & 26,5 \\
\hline Total & 305 & 102 & 407 \\
$(\%)$ & 75 & 25 & 100 \\
\hline
\end{tabular}

Fonte: AMRC. Seção Judiciário. Livro de Notas do Tabelionato. Série cartas de liberdade.

Não se deixou de registrar nos livros de notas do tabelionato de Rio de Contas senhoras envolvidas na concessão de alforrias para escravos domésticos. Todavia, a participação das mulheres em muitos negócios nem sempre se tornou visível pelas condições da legislação brasileira oitocentista que, conforme avaliou Maria Odila Leite Dias $(2004)^{54}$ em recente palestra, criou um sistema como entidade universal do público cujo sujeito é o homem e, desse modo, aparentava realizações exclusivamente masculinas. Não se quer desprezar aqui as condições econômicas regionais, muito voltadas para as lidas nas fazendas e tropas, ou mesmo uma mentalidade muito arraigada à prevalência masculina. Ao contrário, procura-se relacionar essa situação também na promoção de uma invisibilidade feminina em testamentos e inventários, antes da morte de seus maridos. Invisíveis, mas sugestivas. Muitas vezes, nos fóruns e cartórios, 'o cabeça do casal' assinava papéis jurídicos após acordos selados no âmbito da vida doméstica. Porém, a participação mais direta de senhoras em 'negócios' da região também foi registrada na documentação pesquisada e em correspondências pessoais.

Muitas vezes a compra das cartas envolveu uma ação mais coletiva. Mattoso (1990, p.194) considera que "a alforria nunca é uma aventura solitária". Um escravo

pode ser libertado por um membro de sua família, por um padrinho ... Talvez também tenha de pagar apenas uma parte do seu preço, se o senhor se tiver dei- 
xado abrandar e deseja ajudar um pouco seu escravo no duro caminho da conquista da liberdade. (p.191)

Os inventários também notificaram essa questão: “deve ao casal 10\$000, que deu de esmola pela liberdade do escravo Francisco ... o herdeiro José da Luz deve $20 \$ 000$ que deu de esmola para a liberdade do escravo Francisco". ${ }^{55}$

A notificação de ajuda familiar para compra da alforria decorre majoritariamente de uma ação dos pais de crianças escravas: "Maria parda de 5 anos, [cujos pais] pagaram a quantia de Rs. $200 \$ 000$ por sua liberdade” ${ }^{56}$ Como a escravidão levava muitas mulheres a criarem sozinhas seus filhos, algumas dessas "mulheres industriosas [foram] capazes de economizar para comprar a si mesmas ... faziam isso por seus filhos” (Karasch, 2000, p.454). Vários registros assemelham-se ao da "menor Felicidade, parda, de idade de 5 annos pouco mais ou menos ... de cuja mãe n'esta mesma data recebi $400 \$ 000$ pela compra da liberdade da sua filha". ${ }^{57}$ Esses são "apoios necessários" (Mattoso, 1990, p.170) que contribuíam efetivamente para remediar a vida sob o cativeiro.

As barganhas para compras envolviam habilidades de ambas as partes. Notam-se acordos e desacordos nesses 'negócios', amplamente registrados em livros de notas do tabelionato. Vejamos três casos:

Claudino pardo de 48 anos de idade ... Pago pela liberdade a quantia de $200 \$ 000$ reis que exhibindo em $90 \$ 000$ em dinheiro e um recibo de $110 \$ 000$ reis passado por sua ex-senhora. ${ }^{58}$

Manoel Preto, 51 anos, casado com escrava de outrem ... n'este acto foi pelo mesmo escravo apresentada a quantia de 675\$000, e o herdeiro Clemente Antonio Bonfim se obrigasse pelo restante do seu valor [Rs. 900\$000], que é 225\$000, mandou o Juiz que lhe passasse carta de liberdade... ${ }^{59}$

Diferente de Claudino ou Manoel, Luzia enfrentou maiores dificuldades. Alegou, no ano de 1876, que havia sido avaliada "há muitos annos pela quantia de 1:000\$000 ... e não havendo hipothese de alcançar hoje uma escrava mais de $800 \$ 000$, tanto mais quando tem sido a supplicante desmerecido de valor ... requer nova avaliação". ${ }^{60}$ Luzia, assim como muitos escravos no Brasil, recorreu às autoridades "contra o arbítrio ou desonestidade dos senhores" (Reis \& Silva, 1989, p.18).

Apesar das suas alegações o "marido da sua Senhora não aceita a nova avaliação, e defende a manutenção do valor da escrava no inventário 1:050\$000”. Recorreu em seu favor à Lei de 28 de setembro de 1871: “[que] 
não permitia nova avaliação de escravos já inventariados”. Diante da indisposição de seus senhores, a escrava Luzia fez o "depósito de 1:050\$000 para comprar a sua liberdade". ${ }^{11}$ Surpreende uma escrava da época amealhar tal quantia, haja vista que a pesquisa aos inventários indicou que este montante respondia ao total de bens referentes a casas, sítios e gado de muitos lavradores da região. Porém, mostra o quanto foi valioso e oneroso o custo da 'liberdade' para o escravo, que deveria reunir muitos esforços no sentido de alcançá-la, ainda mais considerando os parcos valores dos serviços que prestavam e dos bens que possuíam.

Em Rio de Contas, as cartas de alforria de idosos alcançaram 18,1 por cento na década de 1870, e 11,1 por cento na década seguinte, o que contraria as expectativas traçadas por Mattoso (1990, p.186): "o percentual de alforriados idosos em parte alguma ultrapassa $10 \%$ do total”.

Muitos escravos idosos pagaram elevadas somas pelas suas cartas, como o "africano João", escravo de Dona Anna Maria de Oliveira, cuja carta foi calculada em um conto de réis pela sua liberdade. ${ }^{62}$ Para Mattoso (1990, p.184), "exigir um preço alto do escravo envelhecido [servia para] adquirir um trabalhador novo". Com o declínio da escravidão a partir da década de 1870, a movimentação das vendas de escravos para o Sudeste e a seca da região, é mais provável que os senhores preferissem investir esses valores em suas roças, no comércio, no pagamento de dívidas, e compensar a necessidade de trabalhadores através do aluguel de escravos ou no contrato de diaristas.

Alforriar escravos em idade bastante avançada sob condições e com valores muito elevados favorecia as reações dos escravos? Um processo criminal oferece indício dessa resistência:

vem denunciar á V. S. o liberto Ambrosio, sugeito por força da lei de 28 de setembro de 1885 a três annos de serviços a sua ex-senhora — sua cunhada D. Francisca Joaquina da Gloria Celeste de Jesus - por consideral-o incurso nas penas ... Há annos que a Supplicante com o coração opresso pelas mais cruciantes dores tem visto tombar diversas pessoas de sua principal Família e alguns escravos sem o conhecimento de uma causa plausível para explicar certos syntomas predominantes que manifestavam nos doentes que erão atormentados por vômitos indomáveis. ${ }^{63}$

Caso as mortes tenham resultado de envenenamento promovido por Ambrosio, o que se verifica é a sua revolta contida contra anos de escravidão, tal- 
vez acentuada diante das condições de cartas com termos muito próximos àqueles da Lei dos Sexagenários. ${ }^{64}$

Outras modalidades de pagamento foram experimentadas pelos escravos, em razão das dificuldades em adquirir suas alforrias mediante um único pagamento. São as alforrias organizadas em prestações ou pagamentos parcelados.

Em diversas partes do Brasil, os escravos, ao comprarem suas alforrias, insistiam na concessão, negociavam os preços e construíam criativamente estratégias para que fossem concedidas. Conseguiam, muitas vezes, fracionar o pagamento de suas cartas, contando com a confiança de seus senhores, que deveriam esperar pelo pagamento em outra ocasião. Em estudo sobre alforrias mineiras no século XVIII, Eduardo F. Paiva (1995, p.51, grifos nossos), assinala a forte presença das coartações na compra das cartas de liberdade pelos escravos das Minas setecentistas: "Resultados de acordos diretos entre as partes envolvidas, as coartações foram muito comuns na Capitania e, provavelmente, em outras áreas mais urbanizadas da Colônia, como Recife, Olinda, Salvador e Rio de Janeiro".

Kátia Mattoso (1990, p.184) considera:

muitos escravos compram sua alforria a prazo, isto é, pelo sistema de pagamento parcelado. Após 1850, devido à restrição do mercado desde a abolição do tráfico, vinte anos antes, o preço do escravo sobe muito; também disso o senhor se pode aproveitar para auferir grandes lucros.

Realidade não particular, as cartas de liberdade e inventários de Rio de Contas apresentavam freqüentemente o pagamento parcelado, como se pode verificar: O escravo "Antonio cabra", de 39 anos, avaliado em "1:000\$400 reis pagando parcelas no praso de 7 anos e servindo até o praso". ${ }^{65}$ Claudino, "pardo" de 48 anos, pagou pela "liberdade a quantia de 200\$000 reis que exhibindo $90 \$ 000$ em dinheiro e um recibo de $110 \$ 000$ reis passado por sua exsenhora". ${ }^{66}$ Noutra carta, a escrava

Constantina de Manoel Alves de Castro Coelho ... tendo prometido a minha escrava que dando-me $700 \$ 000$ a libertaria, e como até esta data só tenho recebido $500 \$ 000$ para este fim, com condição de inteirar ella a quantia acima dita, lhe concedo liberdade... ${ }^{67}$

Além de os senhores cederem à "condição de inteirar", as prestações demonstram a capacidade do escravo em adquirir a sua carta ou a de seus pa- 
rentes através de arranjos e barganhas no cotidiano, quando economizavam pequenas somas, acumuladas em montantes parcelados, que saíam das suas mãos para as de seus senhores. Muitas delas resultaram de economias guardadas por anos a fio, fruto de labutas no decurso de uma vida.

\section{CARTAS INCONDICIONAIS — GRATUIDADES}

A concessão incondicional das cartas de alforria merece uma referência pontual. O que levou os senhores de Rio de Contas a concederem incondicionalmente, entre 1870 e 1888,114 alforrias ( 28 por cento do montante) aos seus escravos? Buscou-se demonstrar o quanto um escravo era caro aos senhores da região, que enfrentavam dificuldades para comprá-los e mantê-los. Mattoso (2000, p.198) avalia que os senhores mostram nessas cartas que "adoram convencer-se de que agem de acordo com o bom direito e a estrita eqüidade". No entanto, é preciso destituir a idéia de uma "benevolência senhorial" restrita "à oposição maniqueísta entre o bom e mau senhor" (Wissenbach, 1998, p.70), procurando situar a função que exerciam naquela sociedade escravista. Uma primeira característica corresponde à situação já identificada em outros trabalhos no Brasil: justificam-se aparentemente pelos laços constituídos entre senhores e escravos. Mas, tudo leva a crer que no alto sertão as alforrias incondicionais não foram destituídas de negociações entre senhores e escravos, isto é, muitos desses senhores deviam ter assegurado trabalhos gratuitos ou a custos irrisórios de muitos dos seus antigos escravos. Situação que não elimina as relações de amizade, afeto e gratidão que as cartas sugerem. $\mathrm{O}$ senhor Manoel Joaquim Ribeiro de Novais alforriou a sua escrava Ana,

de cor parda de 43 anos, casada com meu escravo João natural de Rio de Contas, filiação desconhecida capaz de trabalho de lavoura ... pelo amor que minha mulher e filhos lhe tem, portanto poderá a escrava de hoje em diante gosar da liberdade como se de ventre livre nascesse. ${ }^{68}$

Nesses termos, ou em termos próximos, foram registradas outras cartas. Algumas trazem menções de pedidos feitos no leito de morte: "pelos bons serviços que prestou a minha finada mulher" ${ }^{9}{ }^{9} \mathrm{O}$ desejo de parentes se faz presente muito comumente: "pelos bons serviços prestados ao dito meo filho, em satisfação dos desejos deste...." 70

Como se conservaram muitos escravos em idade avançada no sertão, algumas cartas se justificam: "por já estar muito velho libertamos Manoel Ramos, 
preto de idade de 73 anos". ${ }^{71}$ Inventários também confirmam essa situação, como o do senhor Manoel Alves de Castro Coelho, que notificou:

Ficão sem valor Rufino, vaqueiro, 50 anos, por estar phthizico, que ficará gozando de plena liberdade pelos bons serviços, Ângela velha e doente de 70 anos, Emerencianna de 60 annos, cega, Francisca de 80 annos, David de 73 annos, e Simplicio de 80 annos, decrepto, os quais ficarão em poder de qualquer dos herdeiros para os alimentar, e proibi-los de mendigar. ${ }^{72}$

Noutra carta, há uma referência muito particular: um escravo herdeiro de seu senhor: "Liberto o escravo Thomas pardo de 80 anos por ser instituído como herdeiro do seu Senhor, por isso poderá gozar de sua liberdade". ${ }^{73}$

No ano de 1888, a senhora Maria da Natividade Barbosa Mello concedeu cartas de liberdade aos escravos Manoel 'pardo', de 25 anos, e Januário 'pardo', de 18 anos, por ocasião da visita de autoridades públicas — decerto de grande importância, apesar de não identificadas pela documentação: "Em homenagem as virtudes dos Ilustres Hospedes, que ora nos honrão". ${ }^{74}$

Voltando à questão inicial, o que levaria os senhores a libertarem seus escravos diante das dificuldades em adquiri-los naquela região? A pesquisa às cartas de liberdade de Rio de Contas indica que, apesar de 'incondicionais', a maior parte delas referem-se a uma situação pregressa, são escravos que haviam se dedicado por muito tempo aos serviços de seus senhores. Mesmo aquelas 'cedidas' aos seus filhos (ainda muito crianças) correspondiam a uma espécie de 'recompensa' aos serviços prestados. Essas cartas foram 'pagas' de diversas maneiras. Além disso, é preciso compreender que muitos desses escravos, mesmo alforriados, permaneceram prestando serviços às famílias de seus antigos senhores, muitos deles coagidos a 'continuar pagando' pela cessão da sua alforria.

\section{Alforrias — UMA QUESTÃo DE GÊNERO E 'COR'?}

Em algumas regiões do Brasil, percebe-se predileção de sexo para concessão das cartas: "os senhores urbanos que libertavam escravos preferiam alforriar um tipo, a escrava negra” (Karasch, 2000, p.451). A mencionada autora identificou, para escravos homens, 479 alforrias, e 840 para escravas mulheres, totalizando 1.319 escravos alforriados no Rio de Janeiro, entre 1807 e 1831 (Karasch, 2000, p.451). Kátia Mattoso (1990, p.185-6) afirmou que é válida para o Rio de Janeiro, Salvador e Parati, a proporção de duas escravas 
para um escravo ("dois terços dos alforriados são mulheres"), situação favorecida por viverem "na intimidade do senhor ou exercerem o ofício de vendedoras ambulantes”. Miridan Knox (1993, p.199), em seu estudo sobre escravidão no Piauí, concluiu que 73,2 por cento das alforrias foram concedidas às mulheres. Considera que o número elevado de alforrias naquela região se relacione às "especificidades da massa escrava", constituída por grande quantidade de crianças e mulheres, e com presença de grande miscigenação.

A Tabela 2 indica pequena diferença de gênero na conquista de cartas de alforria, menos expressiva do que nos estudos aqui apresentados. Como explicar esse equilíbrio? A estratégia adotada aqui consiste em verificar os argumentos que explicam (noutras regiões) maior probabilidade de alforrias entre as escravas. Para Mary Karasch (2000, p.452-3) "as escravas, em especial as mais velhas, custavam geralmente menos que os homens. Portanto, tinham que economizar menos dinheiro para comprar a liberdade" ou "devido a uma relação íntima com sua dona", e ainda, "libertavam suas escravas velhas e enfermas a fim de evitar as despesas com elas".

No alto sertão, muitas escravas e escravos, mesmo aqueles que alcançavam idade elevada, continuavam servindo aos seus antigos senhores. Diante das facilidades ou dificuldades que pesavam na escolha entre ficar ou enfrentar a vida fora do lugar, distante de parentes e amigos, alguns escravos, ao conquistarem alforrias, permaneciam na região, trabalhando como camaradas, vivendo de trabalhos nas roças e em casa de seus antigos senhores ou de pessoas das quais já eram conhecidos. Essa situação se confirma quando se nota que a Lei dos Sexagenários, de 1885, encontrou em Caetité um número muito elevado de escravos idosos (Neves, 1998, p.286).

Uma explicação para essa situação talvez esteja no equilíbrio dos plantéis locais, verificados nos inventários de Rio de Contas, que distinguiram, entre 1860 e 1888, 1.710 escravos, 606 mulheres e 612 homens (além de 418 crianças e 74 idosos).

Outro aspecto é o valor das alforrias, que variava conforme sexo, condições de saúde, profissão e conjuntura. Segundo a pesquisa aos livros de notas do tabelionato de Rio de Contas, da década de 1870, foram alforriadas 151 mulheres, por uma média de Rs. $496 \$ 000$, e 140 escravos do sexo masculino, por uma média de Rs. $778 \$ 000$. Na década de 1880 foram alforriados $74 \mathrm{mu}-$ lheres e 42 homens, e os preços médios sofreram uma redução para Rs. $299 \$ 000$ e Rs. 490\$000, respectivamente. Devemos lembrar que:

As cartas de alforria outorgadas a um preço baseado na estima entre proprietário e escravo subvalorizam o cativo, enquanto o preço dos demais se mantém pró- 
ximo da cotação do mercado de mão-de-obra servil ... Em 1879, a crioula Eugênia, excelente cozinheira, lavadeira e passadeira em casa do seu senhor, em Alagoinhas, pequena cidade do agreste baiano, obtém sua liberdade por 1000000 réis, embora tenha sido avaliada por 1200000 réis. (Mattoso, 1990, p.183, 191) ) $^{75}$

Um estudo de preços de alforria, para período anterior ao fim do tráfico (1807-1831), quando os preços de escravos ainda permaneciam mais baixos, foi realizado por Mary Karasch (2000), que identificou os valores médios de Rs. 160\$000 para homens e Rs. $140 \$ 000$ para mulheres. Esses valores, bem abaixo daqueles de Rio de Contas e Caetité, justificam-se pela permanência do tráfico atlântico, que mantinha os preços dos escravos em patamar menos elevado. Mostram-se, assim, pouco operacionais pelas disparidades da conjuntura e das regiões.

Porém, não há dúvida de que, mesmo distantes das "numerosas oportunidades de uma economia dinâmica urbana”, os escravos, em detrimento do sexo, se esforçaram grandemente para "pagar o preço de uma carta de alforria” (Karasch, 2000, p.440).

Grosso modo, na segunda metade do século XIX, em virtude da miscigenação e do fim do tráfico atlântico, percebe-se que os alforriados eram em sua maioria classificados como 'pardos'. No alto sertão, essa disposição pode ser acompanhada pela Tabela 4:

Tabela 4

Alforrias por gênero, idade, 'cor' e nação, Rio de Contas - 1870-1888

\begin{tabular}{l|cc|cc|cc}
\hline & \multicolumn{2}{|c|}{ Homens } & \multicolumn{2}{c|}{ Mulheres } & \multicolumn{2}{c}{ Crianças } \\
\hline Década & $1870(\%)$ & $1880(\%)$ & $1870(\%)$ & $1880(\%)$ & $1870(\%)$ & $1880(\%)$ \\
\hline Negro/Preto & 12,6 & 19,4 & 12,3 & 43,7 & 6,8 & - \\
Africano & 8,1 & 3,2 & 9,3 & 2,1 & 0,0 & - \\
Cabra & 17,2 & 9,7 & 18,6 & 2,1 & 11,4 & - \\
Crioulo & 23,1 & 9,7 & 22,7 & 2,1 & 25,0 & - \\
Pardo & 33,3 & 58,0 & 34 & 50,0 & 50,0 & - \\
Mulato & 5,7 & 00 & 3,1 & 0,0 & 6,8 & - \\
\hline Total: & 100 & 100 & 100 & 100 & 100 & - \\
\hline
\end{tabular}

Fonte: AMRC. Seção Judiciário. Livros de Notas do Tabelionato. Série Cartas de Liberdade. 
Os estudos de Herbert Klein (1997, p.316) sobre escravos em Sabará (MG), no século XIX, revelam mesma disposição: "Embora os pardos representassem 61 por cento de todos os afro-brasileiros escravos e livres em Sabará, eles compunham 84 por cento das pessoas de cor livres". Tanto no alto sertão quanto em Sabará verifica-se a classificação de 'pardos' para grupos majoritários de escravos. Klein (op. cit., p.317) considera: "os preconceitos raciais da sociedade branca indicavam que a alforria favoreceria os de origem racial mestiça em detrimento de seus companheiros não-mestiços".

Miridan Knox (1993, p.199) afirmou: "A cor não parece ter tido significação nas alforrias. Se 46,7 por cento foram de cor cabra, os escravos mulatos também foram significativamente alforriados, principalmente entre os homens".

Mary Karasch (2000, p.459) examinou, em seu estudo sobre alforrias no Rio de Janeiro, numa conjuntura distinta à deste estudo (1807-1831), a seguinte configuração: "os libertos brasileiros levavam vantagem sobre os africanos. Os 732 brasileiros (56\%) superavam os 504 africanos (38\%) da amostra. Os racialmente misturados estavam em minoria porque parece que a população escrava carioca era esmagadoramente negra."

Apesar de não estabelecer relação entre alforria e 'cor', como fizeram Mary Karasch (2000) e Herbert Klein (1997), a historiadora Kátia Mattoso (1990, p.225) identificou em Salvador (1872) que "44,3 por cento da população baiana foi constituída por mulatos".

Essa disposição da população negra, mais visível na capital da província nos anos finais da escravidão, traça um quadro distinto daquele que se observava no sertão. Talvez as dificuldades - ao menos da ampla maioria dos senhores locais - em adquirir escravos recém-chegados da África, a distância de centros distribuidores de escravos, a grande presença de migrantes pobres e, finalmente, a presença maciça de crianças nascidas na região, tenham contribuído para a miscigenação e reprodução, responsável pela classificação de 'pardos' para um terço dos escravos alforriados em Rio de Contas, na década de 1870 , e metade deles na década seguinte.

Somando essas condições com uma economia pouco especializada, não se observa (ao menos nas fontes pesquisadas) discriminação de 'cor' para ocupação nessa ou naquela função. Os escravos alforriados, identificados em suas profissões, classificados como 'pretos', 'crioulos', 'mulatos,' 'pardos', trabalhavam como ferreiros e lavradores, costureiras, cozinheiras, alfaiates, vaqueiros, "do serviço de carpina", a despeito de distinções de grupos étnicos ou de 'cor'. Do ponto de vista de uma formação mais especializada para o trabalho no 
sertão baiano, é mais provável pensá-la associada à habilidade e ao 'comportamento" de escravos (“é bem insinado" [ sic] ou "obediente ao seu senhor"). Mas, certamente, envolveu a disposição de escravos nesse aprendizado para ampliar margens de 'negociação' com os senhores locais.

As cartas de liberdade e os autos criminais revelam 'arranjos', negociações, meios diversos de que os escravos lançaram mão para se livrarem do cativeiro, de modo que a abolição, ao chegar, encontrou mulheres e homens muito inseridos na vida local, com laços estreitos de vizinhança e, também, senhores ainda muito apegados à manutenção de suas prerrogativas senhoriais, outros mais atentos à instabilidade de uma relação social que rumava para o fim.

\section{NOTAS}

${ }^{1}$ Arquivo Municipal de Rio de Contas. AMRC. Seção Judiciário. Livro de Notas do Tabelionato n.52 (1885-1889). Série cartas de liberdade. Justificativa de uma carta de alforria. Cx. 12 (não classificado), 1887, f.54.

${ }^{2}$ CONRAD, Robert Edgar. Os Últimos Anos da Escravatura no Brasil (1850-1888). 2.ed. Rio de Janeiro: Civilização Brasileira, 1975, p.345.

${ }^{3}$ Durante os primórdios da colonização essa área pertenceu ao morgadio da Casa da Ponte, dos Guedes de Brito, que dividia com os Garcia D’Ávila - Casa da Torre — toda a extensão do território baiano. Joseldeth Gomes (Povoamento da Chapada Diamantina. Rev. do Instituto Geográfico e Histórico da Bahia, Salvador, n.77, p.222-33, p.222) afirma: "Tornou-se então, propriedade quase exclusiva dos D'Ávilla e Guedes de Brito, toda a extensão desde Urubu (atual Paratinga) até abaixo do Salitre, passando pelas cabeceiras dos rios Real, Itapicurú e Inhambupe. Até 1663 estava apropriada toda a margem bahiana do grande rio". Em NEVES, Erivaldo Fagundes. Uma comunidade sertaneja: da sesmaria ao minifúndio (um estudo de história regional e local). Salvador: Ed. UFBA; Feira de Santana: Universidade Estadual de Feira de Santana, 1998, p.22: a região do "Alto Sertão da Bahia é referenciada na posição relativa ao curso do rio São Francisco na Bahia e ao relevo baiano, que ali projeta as maiores altitudes".

${ }^{4}$ Cf. NEVES (1998, p.204) e NEVES, Erivaldo Fagundes. Sampauleiros traficantes: comércio de escravos do Sertão da Bahia para o Oeste Cafeeiro Paulista. Afro-Ásia, Salvador, n.24, p.97-128, 2000, p.106. O termo de Caetité era composto de três freguesias: "Santa Anna de Caetité", Nossa Senhora do Rosário do Gentio (atual Ceraíma, distrito de Guanambi) e Santíssimo Sacramento de Santo Antônio da Barra (Condeúba).

${ }^{5}$ BARICKMAN, B. J. Um contraponto baiano: açúcar, fumo, mandioca e escravidão no Recôncavo, 1780-1860. Rio de Janeiro: Civilização Brasileira, 2003. 
${ }^{6}$ DANTAS, Mônica Duarte. Fronteiras movediças: relações sociais na Bahia do século XIX (a comarca de Itapicuru e a formação do arraial de Canudos). 2002, $421 \mathrm{f}$. (Tese de Doutorado em História Social). Faculdade de Filosofia, Letras e Ciências Humanas, Universidade de São Paulo, 2002.

${ }^{7}$ Ver ALGRANTI, Leila Mezan. Criminalidade escrava e controle social no Rio de Janeiro (1810-1821). Revista Estudos Econômicos, São Paulo: Instituto de Pesquisas Econômicas IPE, n.18, p.45-80, 1988; BOTELHO, Tarcísio R. As alforrias em Minas Gerais no século XIX. Revista Varia História, n.23, p.61-76, jul. 2000; CHALHOUB, Sidney. Visões da liberdade: uma história das últimas décadas da escravidão na corte. São Paulo: Companhia das Letras, 1990; EISENBERG, Peter. Ficando livre: as alforrias em Campinas no século XIX. Estudos Econômicos, São Paulo, v.17, n.2, 1987; KARASCH, Mary. A vida dos escravos no Rio de Janeiro (1808-1850). São Paulo: Companhia das Letras, 2000; KLEIN, Herbert S.; PAIVA, Clotilde Andrade. Libertos em uma economia escravista: Minas Gerais em 1831. Estudos Econômicos, São Paulo, USP/IPE, v.27, n.2, p.177-335, 1997; KNOX, Miridan Britto. Escravos do sertão. Demografia, trabalho e relações sociais — Piauí - 1826-1888. 1993. 277 f. Tese (Doutorado em História Social) — Faculdade de Filosofia, Letras e Ciências Humanas, Universidade de São Paulo, 1993, p.199); MATTOSO, Kátia de Queirós. A carta de alforria como fonte complementar para o estudo da rentabilidade da mão-de-obra escrava (1819/1888). In: PELAEZ, M.; BESCI, M. (Ed.) A moderna história econômica. São Paulo: Apec, 1975; MOTTA, José Flávio. Corpos escravos, vontades livres: posse de cativos e família escrava em Bananal (1801-1829). São Paulo: Fapesp; Annablume, 1999; OLIVEIRA, Maria Inês Côrtes de. O liberto: seu mundo e os outros. Salvador (BA): Corrupio; Brasília: CNPq, 1988; PAIVA, Eduardo França. Coartações e alforrias nas Minas Gerais do século XVIII: as possibilidades de libertação escrava no principal centro colonial. Revista de História, São Paulo, n.133, p.49-57, $2^{\circ}$ semestre, 1995; SLENES, Robert W.; MELLO, Pedro Carvalho de. Paternalism and Social Control in a Slave Society: the coffee regions of Brazil, 1850-1888. In: CONGRESSO DE SOCIOLOGIA, 9, Uppsala, 1978. (Mimeogr.)

${ }^{8}$ Para o período de $1870-1888$ pesquisei um total de 352 cartas, sendo 226 do período de 1870-1879 e 126 do período de 1880-1888, totalizando 407 escravos alforriados, juntamente com as escrituras públicas de compra e venda de escravos (268 registros, com 385 escravos vendidos entre os anos 1860-1888), que correspondem aos livros de notas do Tabelionato (números 42 a 52), perfazendo oito livros sob guarda do Arquivo Municipal de Rio de Contas - AMRC.

${ }^{9}$ Foram pesquisados, em números absolutos, os escravos registrados nos inventários de Rio de Contas para o período de 1860-1888. Da década de 1860, somente foi possível fazer o levantamento de 48 inventários referentes ao período de 1860-1865 (anos de abertura e encerramento de inventários). Dessa forma é possível estabelecer parâmetros entre inventários, escrituras públicas de compra e venda e cartas de alforria.

${ }^{10}$ SILVA, Ricardo Tadeu C. Os escravos vão à Justiça: a resistência escrava através das ações de liberdade. Bahia, século XIX. Dissertação de mestrado (UFBA, 2000). 
${ }^{11}$ PIRES, Maria de Fátima Novaes. O crime na cor: a experiência de escravos e forros no alto Sertão da Bahia — Rio de Contas e Caetité - 1830-1888. São Paulo: Annablume, 2003. ${ }^{12}$ MATTOSO, Kátia de Queirós. Ser escravo no Brasil. 3.ed. São Paulo: Brasiliense, 1990.

${ }^{13}$ SILVA, Eduardo. Dom Obá d'África, o príncipe do povo: vida, tempo e pensamento de um homem livre de cor. São Paulo: Companhia das Letras, 1997.

${ }^{14}$ REIS, João José; SILVA, Eduardo. Negociação e conflito: a resistência negra no Brasil escravista. São Paulo: Companhia das Letras, 1989.

${ }^{15}$ AMRC. Seção Judiciário. Livro de Notas do Tabelionato n.45 (1868-71). Série cartas de liberdade. Cx. 11 (não classificado), 1869, f.51.

${ }^{16}$ Loc. cit., 1870, f.64.

${ }^{17}$ AMRC. Seção Judiciário. Livro de Notas do Tabelionato n.46 (1871-74). Série cartas de liberdade. Cx. 11 (não classificado), 1873, f.50.

${ }^{18}$ Loc. cit., f.73 e $73 v$.

${ }^{19}$ AMRC. Seção Judiciário. Livro de Notas do Tabelionato n.45 (1868-71). Série cartas de liberdade. Cx. 11 (não classificado), 1868-70, f.59.

${ }^{20}$ AMRC. Seção Judiciário. Livro de Notas do Tabelionato n.51 (1882-85). Série cartas de liberdade. Cx. 12 (não classificado), 1884, f.68.

${ }^{21}$ AMRC. Seção Judiciário. Livro de Notas do Tabelionato n.45 (1868-71). Série cartas de liberdade. Cx. 11 (não classificado), 1869-70, f.46v.

${ }^{22}$ AMRC. Seção Judiciário. Livro de Notas do Tabelionato n.50 (1879-82). Série cartas de liberdade. Cx. 11 (não classificado), 1871, f.88v.

${ }^{23}$ AMRC. Seção Judiciário. Livro de Notas do Tabelionato n.45 (1868-71). Série cartas de liberdade. Cx. 11 (não classificado), 1871, f.88v.

${ }^{24}$ AMRC. Seção Judiciário. Livro de Notas do Tabelionato n.52 (1885-89). Série cartas de liberdade. Cx. 12 (não classificado), 1887, f.54.

${ }^{25}$ AMRC. Seção Judiciário. Livro de Notas do Tabelionato n.48 (1875-78). Série cartas de liberdade. Cx. 11 (não classificado), 1874-77, f.119.

${ }^{26}$ AMRC. Seção Judiciário. Livro de Notas do Tabelionato n.45 (1868-71). Série cartas de liberdade. Cx. 11 (não classificado), 1869, f.88v.

${ }^{27}$ Arquivo Público do Estado da Bahia (Apeb). Seção Judiciário. Série Inventários. ID: Marcolino José Barbosa. Est. 03, cx. 1213, maço 1682, doc. 07, 1878-79, auto com 86 f., f.31.

${ }^{28}$ GEBARA, Ademir. O mercado de trabalho livre no Brasil (1871-1888). São Paulo: Brasiliense, 1986.

${ }^{29}$ AMRC. Seção Judiciário. Livro de Notas do Tabelionato n.45 (1868-71). Cx. 11 (não classificado), 1871, f.89-89v., grifos nossos. 
${ }^{30}$ Sobre este aspecto, Mattoso (1990, p.197) afirma: "A literatura, a tradição, adoraram contar histórias desses bastardos, nascidos das relações entre senhores e escravas. É certo, e as provas aqui são abundantes, que os bastardos são, em geral, libertados ainda crianças e gratuitamente".

${ }^{31}$ AMRC. Seção Judiciário. Livro de Notas do Tabelionato n.46 (1871-74). Série cartas de liberdade. Cx. 11 (não classificado), 1858-72, f.8-8v, grifos nossos.

${ }^{32}$ AMRC. Seção Judiciário. Livro de Notas do Tabelionato n.46 (1871-74). Série cartas de liberdade. Cx. 11 (não classificado), 1873, f.56v., grifos nossos.

${ }^{33}$ AMRC. Seção Judiciário. Livro de Notas do Tabelionato n.46 (1871-74). Série cartas de liberdade. Cx. 11 (não classificado), 1872-73, f.61 v.

${ }^{34}$ AMRC. Seção Judiciário. Livro de Notas do Tabelionato n.46 (1871-74). Série cartas de liberdade. Cx. 11 (não classificado), 1873, f.64.

${ }^{35}$ AMRC. Seção Judiciário. Livro de Notas do Tabelionato n.48 (1875-78). Série cartas de liberdade. Cx. 11 (não classificado), 1875-77, f.165.

${ }^{36}$ AMRC. Seção Judiciário. Livro de Notas do Tabelionato n.48 (1875-78). Série cartas de liberdade. Cx. 11 (não classificado), 1872-78, f.184-184v.

${ }^{37}$ AMRC. Seção Judiciário. Livro de Notas do Tabelionato n.51 (1885-89). Série cartas de liberdade. Cx. 12 (não classificado), 1886-87, f.49.

${ }^{38}$ BARICKMAN, B. J. Até a véspera: o trabalho escravo e a produção de açúcar nos engenhos do Recôncavo Baiano (1850-1881). Revista Afro-Ásia, Salvador, n.21-22, p.177-238, 1998-1999.

${ }^{39}$ AMRC. Seção Judiciário. Livro de Notas do Tabelionato n.48 (1870-76). Série cartas de liberdade. Cx. 11 (não classificado), 1872-73, f.90.

${ }^{40}$ MATTOS, Hebe Maria. Das cores do silêncio: os significados da liberdade no Sudeste escravista, Brasil Século XIX. 2.ed. Rio de Janeiro: Nova Fronteira, 1998.

${ }^{41}$ AMRC. Seção Judiciário. Livro de Notas do Tabelionato n.46 (1875-78). Série cartas de liberdade. Cx. 11 (não classificado), 1872-73, f.60v.

${ }^{42}$ WISSENBACH, Maria Cristina C. Sonhos africanos, vivências ladinas: escravos e forros em São Paulo (1850-1880). São Paulo: Hucitec; História Social, USP, 1998.

${ }^{43}$ Apeb. Seção Executivo. Série: Escravos. Maço 2892, documento avulso, março de 1876 (não consta deferimento ao final), f. não enumerada.

${ }^{44}$ MACHADO, Maria Helena P. T. Em torno da autonomia escrava: uma nova direção para a história social da escravidão. Revista Brasileira de História, São Paulo, v.8, n.16, p.14360, mar.-ago. 1988.

${ }^{45}$ SPIX, Johann Baptiste von; MARTIUS, Carl Friedrich Phillipp von. Através da Bahia. 
Excertos da obra Viagem pelo Brasil (1817-1820), editados e anotados pelo Dr. Manoel A. Pirajá da Silva e Dr. Paulo Wolf, Salvador: Imprensa Official do Estado, 1916.

${ }^{46}$ SANTOS FILHO, Lycurgo. Uma comunidade rural do Brasil antigo - aspectos da vida patriarcal no sertão da Bahia nos séculos XVIII e XIX. São Paulo: Cia. Ed. Nacional, 1956.

${ }^{47}$ AMRC. Seção Judiciário. Livro de Notas do Tabelionato n.51 (1885-89). Série cartas de liberdade. Cx. 11 (não classificado), 1887, f.55.

${ }^{48}$ NEVES, 1998, p.251-2, grifo nosso: "Pelo sistema da sorte, recebia, conforme contratado, um de cada quatro, cinco ou seis bezerros dos que ferrasse, anualmente, no gado sob seus cuidados ... Denominavam também de giz esse sistema que retribuía o vaqueiro com aproximadamente $25 \%$ da produção do gado, no final do quatriênio contratado ... O regime de sorte estendia-se, eventualmente, aos criatórios de eqüinos e muares das mesmas fazendas de gado e mais raramente às miúças - ovinos, caprinos e suínos - típicas de pequenos criadores, para autoconsumo". Deve-se lembrar que as reses perdidas ou mortas eram descontadas do quinhão do vaqueiro.

${ }^{49}$ AMRC. Seção Judiciário. Livro de Notas do Tabelionato n.46 (1871-74). Série cartas de liberdade. Cx. 11 (não classificado), 1875, f.37.

${ }^{50}$ AMRC. Seção Judiciário. Livro de Notas do Tabelionato n.48 (1875-78). Série cartas de liberdade. Cx. 11 (não classificado), 1875, f.11.

${ }^{51}$ AMRC. Seção Judiciário. Série Inventários. ID: Cap. José Manoel do Bomfim. Cx. 93 (não classificado), 1874-82, auto com 259 f., f.14v.-15.

${ }^{52}$ AMRC. Seção Judiciário. Livro de Notas do Tabelionato n.48 (1875-78). Série cartas de liberdade. Cx. 11 (não classificado), 1877, f.117, grifos nossos.

${ }^{53}$ AMRC. Seção Judiciário. Livro de Notas do Tabelionato n.45 (1868-71). Série cartas de liberdade. Cx. 11 (não classificado), 1871, f.81, grifos nossos.

${ }^{54}$ DIAS, Maria Odila Leite da Silva. Anais do ENCONTRO REGIONAL DE HISTÓRIA, XVII, da Associação Nacional de História - Anpuh, Núcleo Regional de São Paulo. Campinas, 6 a 10 set. 2004, IFCH, Unicamp.

${ }^{55}$ AMRC. Seção Judiciário. Série Inventários. ID: Salvador da Luz Soares. Cx. 91 (não classificado), 1873-1882, auto com 127 f., f.22v.

${ }^{56}$ AMRC. Seção Judiciário. Livro de Notas do Tabelionato n.47 (1874-75). Série cartas de liberdade. Cx. 11 (não classificado), 1875, f.95.

${ }^{57}$ AMRC. Seção Judiciário. Livro de Notas do Tabelionato n.45 (1868-71). Série cartas de liberdade. Cx. 11 (não classificado), 1869, f.59.

${ }^{58}$ AMRC. Seção Judiciário. Livro de Notas do Tabelionato n.48 (1875-78). Série cartas de liberdade. Cx. 11 (não classificado), 1877, f.210.

${ }^{59}$ AMRC. Seção Judiciário. Série Inventários. ID: Vitorino José de Miranda. Cx. 96 (não classificado), 1878-95, auto com 220 f., f.9v.-10, grifos nossos. 
${ }^{60}$ Apeb. Seção Judiciário. Série Inventários. ID: Francisco Fialho de Carvalho. Est. 03, cx. 1198, maço 1667, doc. 17, 1870-1891, f.76.

${ }^{61}$ Loc. cit., f.91.

${ }^{62}$ AMRC. Seção Judiciário. Livro de Notas do Tabelionato n.45 (1868-71). Série cartas de liberdade. Cx. 11 (não classificado), 1870, f.96v.

${ }^{63}$ AMRC. Seção Judiciário. Processo-crime de 02.01 .1888 (não classificado), f. não enumeradas, grifos nossos.

${ }^{64}$ Observe-se: "A lei de 28 de setembro de 1885, a 'lei dos sexagenários', que emancipa todos os adultos de mais de 60 anos, também determina que o escravo liberto deve indenizar seu senhor e, se incapaz de fazê-lo em dinheiro, fica convencionado que os escravos entre 60 e 62 trabalharão mais 3 anos, e os demais até aos 65 anos." (MATTOSO, 1990, p.179). "Declara que os libertos de 63 anos estão sujeitos à prestação de serviços até que completem 65 anos de idade." (FENELON, Déa Ribeiro. Levantamento e sistematização da legislação relativa aos escravos no Brasil. In: SIMPÓSIO DE PROFESSORES UNIVERSITÁRIOS DE HISTÓRIA, 6, Anais... São Paulo, v.2, p.199-307, 1973, p.280).

${ }^{65}$ AMRC. Seção Judiciário. Livro de Notas do Tabelionato n.50 (1879-82). Série cartas de liberdade. Cx. 11 (não classificado), 1880, f.78.

${ }^{66}$ AMRC. Seção Judiciário. Livro de Notas do Tabelionato n.48 (1875-78). Série cartas de liberdade. Cx. 11 (não classificado), 1872-78, f.210.

${ }^{67}$ AMRC. Seção Judiciário. Livro de Notas do Tabelionato n.45 (1868-71). Série cartas de liberdade. Cx. 11 (não classificado), 1871, f.82v.

${ }^{68}$ AMRC. Seção Judiciário. Livro de Notas do Tabelionato n.48 (1875-78). Série cartas de liberdade. Cx. 11 (não classificado), 1876, f.167.

${ }^{69}$ AMRC. Seção Judiciário. Livro de Notas do Tabelionato n.45 (1868-71). Série cartas de liberdade. Cx. 11 (não classificado), 1871, f.85

${ }^{70}$ AMRC. Seção Judiciário. Livro de Notas do Tabelionato n.46 (1871-74). Série cartas de liberdade. Cx. 11 (não classificado), 1873, f.62

${ }^{71}$ AMRC. Seção Judiciário. Livro de Notas do Tabelionato n.47 (1874-75). Série cartas de liberdade. Cx. 11 (não classificado), 1875, f.64.

${ }^{72}$ AMRC. Seção Judiciário. Série Inventários. ID: Manoela Sofia de Castro. Cx. 91 (não classificado), 1873, auto com 29 f., f.13.

${ }^{73}$ AMRC. Seção Judiciário. Livro de Notas do Tabelionato n.45 (1868-71). Série cartas de liberdade. Cx. 11 (não classificado), 1880, f.82.

${ }^{74}$ AMRC. Seção Judiciário. Livro de Notas do Tabelionato n.51 (1885-89). Série cartas de liberdade. Cx. 12 (não classificado), 1888, f.76.

${ }^{75}$ Os índices levantados pelo estudo de Mattoso (1990, p.96), embora se destinem ao estu- 
do da formação de "preços" para venda, auxiliam uma comparação mais plausível. A média alcançada por escravas e escravos na capital da província, nas décadas de 1870 e 1880, indica: mulheres, de Rs. $975 \$ 000$ para Rs. 410\$000, homens, de Rs. 1:230\$000 para Rs. $600 \$ 000$, para os respectivos períodos. 